\title{
PERBEDAAN KONSENTRASI PEWARNA ALAMI KULIT BUAH NAGA (Hylocereus polyrhizus) TERHADAP WARNA TERASI UDANG REBON (Acetes sp.)
}

\author{
THE DIFFERENT PEEL OF DRAGON FRUIT (Hylocereus polyrhizus) CONCENTRATION \\ TO COLOR OF SHRIMP (Acetes sp.) PASTE
}

\section{Amelia Ayu Permatasari, Sumardianto, Laras Rianingsih}

\author{
Program Studi Teknologi Hasil Perikanan, Jurusan Perikanan, Fakultas Perikanan dan Ilmu Kelautan, Universitas \\ Diponegoro \\ J1. Prof. Soedarto, SH, Tembalang, Semarang, Jawa Tengah-50275, Telp/Fax. +62247474698 \\ Email: ameliaayup11@gmail.com
}

Diserahkan [10 Agustus 2017]; Diterima [10 Desember 2017]; Dipublikasi [26 Februari 2018]

\section{ABSTRACT}

Shrimp paste is one of fermented product that use either shrimp (Acetes sp.), or fish, or both of them as raw materials. The use of synthetic dyes on shrimp paste is still often done. This is dangerous because it can give bad effect to the health of consumers. Therefore, it is necessary to use natural dyes instead of synthetic dyes. One of natural dyes that can be used is peel of dragon fruit (Hylocereus polyrhizus). Peel of dragon fruit has anthocyanin pigment that can give red color. The aimed of this research was knowing the effect of adding peel of dragon fruit extract $(30 \% ; 35 \% ; 40 \%)$ to the color of shrimp paste. The treatments in this study were the addition of different concentrations of peel of dragon fruit extract at third grinding shrimp paste in triplicate. The experimental design used was Completely Randomized Design. The parameters observed include moisture content, salt content, protein content, $\mathrm{pH}$, color, and sensory. Parametric data analyzed by Analysis of Variance (ANOVA) and further test by Honestly Significant Difference (HSD) test if these any differences between samples. Non-parametric data analyzed by Kruskal-Wallis and further test by Mann Whitney. The research's result showed that processing shrimp paste with different peel of dragon fruit extract concentrations gave significant effect $(P<5 \%)$ on moisture content, salt content, $\mathrm{pH}$, and color. Moisture content values was ranged from 35,07$41,01 \%$ and salt content values was ranged from 6,35-7,05\%. pH values was ranged from 6,40-7,20. Shrimp paste with peel of dragon fruit extract $40 \%$ had more red color and improve the appearance of shrimp paste.

Keywords: shrimp paste, color, peel of dragon fruit, anthocyanin

\section{ABSTRAK}

Terasi merupakan salah satu produk fermentasi berbahan baku udang rebon (Acetes sp.), ikan atau keduanya. Penggunaan bahan pewarna sintetis pada pembuatan terasi masih sering dilakukan. Hal ini berbahaya karena dapat memberikan efek yang buruk bagi kesehatan konsumen. Oleh karena itu, diperlukan penggunaan pewarna alami sebagai pengganti pewarna sintetis. Salah satu pewarna alami yang dapat digunakan adalah kulit buah naga (Hylocereus polyrhizus). Kulit buah naga mengandung zat warna antosianin yang dapat memberikan warna merah. Tujuan dari penelitian ini adalah untuk mengetahui pengaruh penambahan ekstrak kulit buah naga $(30 \% ; 35 \% ; 40 \%)$ terhadap warna terasi udang. Penelitian ini dilakukan dengan penambahan konsentrasi ekstrak kulit buah naga yang berbeda pada terasi udang saat proses penggilingan III dengan tiga kali ulangan. Rancangan penelitian ini menggunakan pola percobaan Rancangan Acak Lengkap. Parameter uji yang dilakukan adalah uji kadar air, kadar garam, pH, kadar protein, warna, dan sensori. Data parametrik dianalisis dengan uji Analysis of Variance (ANOVA) dan dilanjutkan uji Beda Nyata Jujur (BNJ) jika terdapat perbedaan perlakuan antara sampel. Data non-parametrik dianalisis dengan Kruskal-Wallis dan dilanjutkan dengan uji lanjut MannWhitney. Hasil penelitian menunjukkan bahwa proses pengolahan terasi udang dengan konsentrasi ekstrak kulit buah naga yang berbeda berpengaruh nyata $(\mathrm{P}<5 \%)$ terhadap nilai kadar air, kadar garam, $\mathrm{pH}$, dan warna. Nilai kadar air terasi udang berkisar antara 35,07-41,01\% dan nilai garam berkisar antara 6,35-7,05\%. Nilai pH terasi berkisar antara 6,40-7,20. Terasi udang dengan ekstrak kulit buah naga $40 \%$ memiliki warna yang lebih merah dan memperbaiki kenampakan terasi.

Kata kunci: terasi, warna, kulit buah naga, antosianin

\section{PENDAHULUAN}

Terasi merupakan produk fermentasi udang atau ikan dengan penambahan garam dan dengan atau tanpa bahan tambahan lain yang diizinkan. Biasanya terasi digunakan untuk bahan penyedap makanan. Terasi memiliki aroma dan cita rasa khas yang menjadi daya tarik bagi konsumen sehingga 
terasi banyak disukai. Menurut Hariyanto et al. (2013), terasi adalah bumbu masak yang dibuat dari udang yang difermentasikan, berbentuk seperti pasta dan berwarna hitamcoklat menjadi kemerahan bila ditambah bahan pewarna. Terasi memiliki bau yang tajam dan biasanya digunakan untuk membuat sambal terasi, tapi juga divariasikan dalam berbagai resep tradisional Indonesia. Ciri khas terasi adalah aromanya yang agak tajam dan rasanya gurih. Hal ini juga diperkuat oleh Suprapti (2006), terasi udang umumnya memiliki rasa lebih enak dibandingkan dengan terasi ikan. Produk berbahan baku ikan-ikan kecil atau rebon tersebut diolah melalui proses pemeraman atau fermentasi.

Warna asli terasi adalah coklat kehitaman seperti warna tanah. Warna tersebut kurang menarik bagi konsumen sehingga terasi menjadi kurang diminati. Warna pada terasi penting untuk diperhatikan karena warna merupakan salah satu aspek dalam penerimaan konsumen terhadap suatu produk pangan. Tetapi untuk lebih menarik minat para konsumen, seringkali terasi diwarnai dengan warna yang mencolok menggunakan pewarna sintesis yang berbahaya bagi kesehatan. Menurut Sari et al. (2009), sering terjadi penggunaan pemakaian zat warna untuk bahan pangan, misalnya zat pewarna untuk tekstil dan kulit dipakai untuk mewarnai bahan pangan. Hal ini jelas sangat berbahaya bagi kesehatan karena ada residu logam berat pada zat pewarna tersebut.

Penggunaan pewarna alami pada produk pangan merupakan salah satu alternatif untuk mengatasi masalah penggunaan pewarna sintesis. Salah satu pewarna alami yang dapat digunakan adalah dari kulit buah naga (Hylocereus polyrhizus). Kulit buah naga merupakan salah satu limbah makanan yang dapat dimanfaatkan menjadi pewarna alami. Kulit buah naga yang berkisar 30-35\% dari total keseluruhan berat buah naga ini memiliki beberapa keunggulan dibandingkan dengan dagingnya. Kandungan zat warna alami yang terdapat pada kulit buah naga adalah antosianin. Antosianin dapat memberikan warna merah sehingga baik untuk dijadikan sebagai pewarna alami. Menurut Citramukti (2008), ekstrak kulit buah naga merah mengandung antosianin 26,4587 ppm. Antosianin merupakan zat warna yang berperan memberikan warna merah berpotensi menjadi pewarna alami untuk pangan dan dapat dijadikan alternatif pengganti pewarna sintesis yang lebih aman bagi kesehatan. Hal tersebut juga diperkuat oleh Li et al. (2006), kulit buah naga merah mempunyai kandungan pigmen alami yang dapat dijadikan alternatif pengganti pewarna sintetis sehingga menghilangkan keraguan akan berakibat buruk pada kesehatan. Berdasarkan uraian tersebut, maka perlu dilakukan penelitian mengenai pengaruh perbedaan penambahan konsentrasi pewarna alami ekstrak kulit buah naga (Hylocereus polyrhizus) terhadap warna terasi udang rebon (Acetes sp.).

\section{METODE PENELITIAN}

\section{Bahan dan Alat}

Bahan yang digunakan adalah kulit buah naga dan aquades untuk membuat ekstrak kulit buah naga, sedangkan udang rebon, garam, dan air untuk membuat terasi. Alat yang digunakan adalah gelas ukur, beaker glass, stoples kaca, dan timbangan digital untuk membuat ekstrak kulit buah naga, sedangkan mesin penggiling, baskom, dan stoples plastik untuk membuat terasi.

\section{Pembuatan Ekstrak Kulit Buah Naga (Saati, 2009)}

Proses pembuatan ekstrak kulit buah naga yaitu dengan sortasi kulit buah naga, kemudian dilakukan penghancuran. Selanjutnya dilakukan ekstraksi dengan cara maserasi selama 24 jam menggunakan pelarut aquades (1:6), kemudian dilakukan sentrifuse (5 menit $5000 \mathrm{rpm}$ ). Penyaringan dilakukan setelah sentrifuse untuk mendapatkan filtrat antosianin. Selanjutnya dilakukan penguapan menggunakan rotary evaporator dengan suhu $50^{\circ} \mathrm{C}$ untuk mendapatkan ekstrak antosianin.

\section{Pembuatan Terasi (Rahmayati et al., 2014)}

Proses pembuatan terasi yaitu dilakukan penjemuran udang rebon terlebih dahulu, selanjutnya dilakukan proses penggilingan I dengan penambahan garam $15 \%$ kemudian disimpan 1 malam. Penjemuran II dilakukan hingga adonan 
menjadi kering. Selanjutnya dilakukan penggilingan II dan kembali disimpan 1 malam. Penggilingan III dilakukan dengan menambahkan ekstrak kulit buah naga sesuai perlakuan $(0 \%, 30 \%, 35 \%$, dan $40 \%)$. Selanjutnya dilakukan proses pencetakan, kemudian dilakukan penjemuran III dan disimpan 1 malam. Keesokan harinya, kembali dilakukan penjemuran sebelum terasi dikemas. Fermentasi terasi dilakukan selama 30 hari setelah dilakukan pengemasan.

Uji Kadar Air (SNI No. 2354.2-2006, 2006)

Prosedur pengujian kadar air adalah dengan memasukkan cawan kosong ke dalam oven minimal 2 jam, kemudian cawan kosong dimasukkan ke dalam desikator selam 30 menit sampai mencapai suhu ruang dan timbang bobot kosong (Ag). Selanjutnya memasukkan sampel yang dihaluskan sebanyak \pm 2 g ke dalam cawan $(\mathrm{Bg})$ dan ditimbang kembali, kemudian memasukkan cawan yang telah diisi sampel ke dalam oven selama 12 jam pada suhu $100^{\circ} \mathrm{C}$ sampai $105^{\circ} \mathrm{C}$. Setelah itu cawan dipindahkan dengan menggunakan alat penjepit ke dalam desikator \pm 30 menit kemudian timbang $(\mathrm{Cg})$. \%kadar air $=\frac{\mathrm{B}-\mathrm{C}}{\mathrm{B}-\mathrm{A}} \times 100 \%$

Keterangan:

A: berat cawan kosong, dinyatakan dalam g

B: berat cawan kosong +contoh awal, dinyakan dalam $g$

C: berat cawan kosong +contoh kering, dinyatakan dalam $\mathrm{g}$

\section{Uji Kadar Garam (SNI No. 01-2891-1992,} 1992)

Prosedur pengujian kadar garam adalah kristal garam yang melekat pada sampel dicuci dengan larutan $\mathrm{NaCl}$ jenuh, sampel diletakan dan ditiriskan pada penyaring kwarsa selama 5 menit. Sampel diblender hingga homogen dan diletakan pada wadah yang bersih dan ditutup rapat. Sampel ditimbang sebanyak $3 \mathrm{~g}$ dan dimasukan kedalam Erlenmeyer $250 \mathrm{ml} . \mathrm{AgNO}_{3} 0,1 \mathrm{~N}$ sebanyak $25 \mathrm{ml}$ dimasukkan dan $\mathrm{HNO}_{3}$ pekat. Sampel dididihkan dengan hotplate. Air bebas halogen ditambahkan sebanyak $50 \mathrm{ml}$ dan dinginkan. Indicator ferri ditambahkan sebanyak $3 \mathrm{ml}$ dan di titrasi dengan $\mathrm{NH}_{4} \mathrm{CNS}$ 0,1 N sampai larutan berwarna coklat muda permanen.

\section{Uji pH (AOAC, 2005)}

Analisis $\mathrm{pH}$ menggunakan alat Hanna 213. Sebanyak $5 \mathrm{~g}$ sampel dilarutkan dalam $20 \mathrm{ml}$ aquades dan dihomogenkan. Selanjutnya suhu sampel diukur untuk digunakan sebagai suhu acuan $\mathrm{pH}$ meter yang digunakan. $\mathrm{pH}$ meter, kemudian dinyalakan dan dibiarkan hingga stabil terlebih dahulu, kemudian elektroda dicelupkan ke dalam sampel hingga beberapa saat sampai diperoleh angka yang stabil pada proyektor $\mathrm{pH}$ meter.

\section{Uji Kadar Protein (SNI No. 01-2716-2006, 2006)}

Penentuan kadar protein pada sampel terasi udang rebon dilakukan dengan menggunakan metode Mikro Kjeldahl. Pada dasarnya dibagi menjadi tiga tahapan yaitu proses destruksi yaitu 2 gram sampel ditimbang dan dimasukkan ke dalam labu kjeldahl kemudian ditambahkan ke dalam labu 2 butir tablet katalis, $15 \mathrm{ml} \mathrm{H}_{2} \mathrm{SO}_{4}$ pekat. Selanjutnya dipanaskan dengan alat destruksi di lemari asam dengan suhu $450^{\circ} \mathrm{C}$ selama 2 jam (sampai contoh jernih). Tahap selanjutnya adalah destilasi yaitu $100 \mathrm{ml}$ aquades ditambahkan ke dalam labu hasil destruksi kemudian dimasukkan labu tersebut ke dalam alat destilasi uap dan ditambah 10

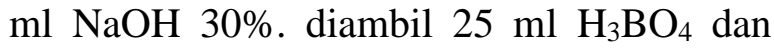
dimasukkan ke dalam erlenmeyer $250 \mathrm{ml}$ dan ditambahkan 2 tetes indikator methyl red kemudian alat destilasi dipasangkan. Selanjutnya dititrasi dengan larutan standar HCL 0,2 $\mathrm{N}$ hingga larutan berubah warna dari kuning menjadi merah muda (pink).

Kadar Protein (\%)

$$
=\frac{(\mathrm{Va}-\mathrm{Vb}) \mathrm{HCl} \times \mathrm{N} \mathrm{HCl} \times 14,007 \times 6,25 \times 100 \%}{\mathrm{~W} \times 1000}
$$

Keterangan:

Va : volume titran sampel

$\mathrm{Vb}$ : volume tritran blanko

$\mathrm{N}$ : konsentrasi HCL $(0,2 \mathrm{~N})$

$\mathrm{W}$ : berat sampel

14,007 : massa atom Nitrogen

6,25 : konversi protein ikan (16-17\%)

\section{Uji Warna (Instruction Manual, 2002)}

Pengujian warna merupakan salah satu uji untuk mengetahui tingkat kecerahan (L) dan warna yang terbentuk dari suatu bahan, salah satunya terasi. Warna terasi 
dapat ditentukan dengan mengukur nilai a* (komponen (+) merah sampai (-) hijau) dan b* (komponen (+) kuning sampai (-) biru). Pengujian warna dilakukan menggunakan alat Chroma Meter-CR 400. Prosedur kerja pengujian warna adalah sampel terasi utuh disiapkan lalu dipotong menjadi dua bagian. Chromameter disiapkan kemudian dihubungkan dengan arus listrik. Tombol power ditekan untuk menghidupkan alat, kemudian tombol kalibrasi ditekan untuk mengkalibrasi alat. Menu USER CALIB NEW - L*a*b* yang tertera pada layar dipilih dan tombol pengukuran ditekan. Kepala pengukur diletakkan di atas sampel secara horizontal. Pengukuran dapat dimulai ketika lampu indikator menyala. Nilai L, a*, dan $b^{*}$ yang tertera pada layar dicatat. Dilakukan 2-3 kali pengukangan dengan langkah yang sama. Rona pada sampel dapat diketahui dengan meneruskan dalam perhitungan derajat hue ( $\left.{ }^{\circ} \mathrm{Hue}\right)$, menggunakan rumus berikut: ${ }^{\circ} \mathrm{Hue}=$ tan$1\left(b^{*} / a^{*}\right)$ dan untuk mengetahui titik warna dapat menggunakan software color express 1.3.0 dengan memasukkan nilai $\mathrm{a}^{*}, \mathrm{~b}^{*}$, dan $\mathrm{L}$ yang didapat dari chroma meter.

\section{Uji Sensori (SNI 2716:2016, 2016)}

Pengujian sensori merupakan pengujian secara subjektif dari beberapa panelis untuk mengetahui layak atau tidaknya suatu produk perikanan dikonsumsi oleh masyarakat. Pengujian tersebut dilakukan oleh panelis semi terlatih sebanyak 30 orang dengan membandingkan produk yang ada dengan spesifikasi pada scoresheet, kemudian dinilai. Uji sensori meliputi kenampakan, bau, rasa, dan tekstur dengan skala 5-9, dimana untuk kenampakan dengan nilai 5 menyatakan kusam dan kotor, tidak spesifik jenis terasi udang, 7 menyatakan bersih, spesifik jenis terasi udang, dan 9 menyatakan bersih, sangat spesifik jenis terasi udang. Bau dengan nilai 5 menyatakan tidak spesifik terasi udang, 7 menyatakan kurang spesifik terasi udang, dan 9 menyatakan sangat spesifik terasi udang. Rasa dengan nilai 5 menyatakan kurang spesifik terasi udang, 7 menyatakan spesifik terasi udang, dan 9 menyatakan sangat spesifik terasi udang. Tekstur dengan nilai 5 menyatakan tidak padat, kering, mudah hancur, 7 menyatakan padat, kurang kompak, dan 9 menyatakan padat, kompak. Nilai tersebut akan dihitung standar deviasi dan simpangan bakunya sehingga diperoleh suatu interval nilai yang menunjukkan bahwa terasi layak atau tidak layak dikonsumsi. Terasi yang layak dikonsumsi memiliki nilai sensori minimal 7.

\section{Analisis Data}

Rancangan percobaan yang digunakan pada penelitian ini adalah Rancangan Acak Lengkap (RAL) dengan 3 kali ulangan. Perlakuan yang dilakukan adalah penambahan ekstrak kulit buah naga $0 \%$, $30 \%$, 35\%, dan $40 \%$, sedangkan untuk lama fermentasi yang dilakukan adalah selama 30 hari. Parameter yang diuji adalah uji kadar air, uji kadar garam, uji $\mathrm{pH}$, uji kadar protein, dan uji warna pada terasi udang rebon, kemudian diuji Analysis of Variance (ANOVA) untuk mengetahui ada atau tidaknya pengaruh perbedaan nyata. Apabila hasil yang diperoleh menunjukkan perbedaan nyata, maka dilanjutkan dengan uji Beda Nyata Jujur (BNJ) untuk mengetahui perbedaan antar perlakuan.

Data uji non-parametrik yang diperoleh dari hasil uji sensori terasi udang rebon dianalisis dengan uji Kruskal-Wallis untuk mengetahui ada atau tidaknya pengaruh perbedaan nyata dan dilanjutkan dengan uji Mann-Whitney untuk melihat perbedaan antar perlakuan.

\section{HASIL DAN PEMBAHASAN}

\section{Kadar Air Terasi}

Hasil rata-rata nilai kadar air terasi udang rebon (Acetes sp.) dengan perbedaan penambahan konsentrasi pewarna alami ekstrak kulit buah naga (Hylocereus polyrhizus) disajikan pada Tabel 1. Berdasarkan uji kadar air pada terasi yang telah dilakukan, didapatkan nilai berkisar antara 35,07-41,01\%. Nilai tertinggi yang diperoleh yaitu $41,01 \%$ pada terasi $\mathrm{C}$, kemudian 39,04\% pada terasi B, 37,13\% pada terasi $\mathrm{A}$, dan nilai terendah yaitu $35,07 \%$ pada terasi K. Hasil tersebut menunjukkan kadar air terasi sesuai dengan SNI 2716:2016 (2016) yang menyatakan bahwa kadar air terasi maksimal $45 \%$. 
Menurut Fardiaz et al. (1989), dalam Arjuan (2008), terasi yang mempunyai kadar air 26$42 \%$ adalah terasi yang baik, karena apabila kadar air terlalu rendah maka permukaan terasi akan diselimuti oleh kristal-kristal garam dan tekstur terasi menjadi tidak kenyal. Bila kadar air terlalu tinggi maka terasi akan menjadi terlalu lunak.

Tabel 1 Hasil Uji Kadar Air Terasi Udang Rebon (Acetes sp.) dengan Penambahan Pewarna Alami Ekstrak Kulit Buah Naga (Hylocereus polyrhizus)

\begin{tabular}{lc}
\hline \multicolumn{1}{c}{ Perlakuan } & $(\%)$ \\
\hline K $(0 \%)$ & $35,07 \pm 0,18^{\mathrm{a}}$ \\
A $(30 \%)$ & $37,13 \pm 0,85^{\mathrm{b}}$ \\
B $(35 \%)$ & $39,04 \pm 0,68^{\mathrm{c}}$ \\
C $(40 \%)$ & $41,01 \pm 0,16^{\mathrm{d}}$ \\
\hline
\end{tabular}

Keterangan:

- Data merupakan hasil rata-rata 3 kali ulangan \pm standar deviasi

- Data yang diikuti huruf superscript yang berbeda menunjukkan perbedaan nyata $(\mathrm{P}<5 \%)$

Nilai kadar air pada terasi mengalami peningkatan sebesar 5-16\%. Hasil tersebut menunjukkan bahwa semakin tinggi konsentrasi pewarna alami ekstrak kulit buah naga (Hylocereus polyrhizus) yang ditambahkan, maka kadar air pada terasi akan meningkat. Hal ini sesuai dengan penelitian Sanjaya et al. (2016), tentang hasil analisa kadar air terhadap terasi udang rebon dengan penambahan bunga rosella menunjukkan kadar air tertinggi yaitu $49,03 \%$ pada formula penambahan $15 \%$ rosella, kemudian untuk penambahan dengan $10 \%$ rosella yaitu $46,62 \%$, kemudian untuk penambahan dengan $5 \%$ rosella yaitu $45,14 \%$, dan yang terendah yaitu pada terasi tanpa penambahan rosella yaitu $43,19 \%$.

Peningkatan nilai kadar air pada terasi diduga disebabkan karena hasil ekstrak kulit buah naga berbentuk kental. Hasil ekstrak tersebut masih mengandung air sehingga akan meningkatkan air pada produk. Selain itu, kandungan air pada kulit buah naga juga tinggi yaitu sekitar 90\%. Menurut Putri et al. (2015), hasil analisis kadar air pada kulit buah naga merah diperoleh kadar air sebesar 93,57\%. Hal ini sesuai bahwa kadar air pada kulit buah naga sekitar 90,20\%.
Faktor yang dapat menyebabkan peningkatan nilai kadar air adalah penambahan garam. Garam merupakan pengawet alami yang bersifat higroskopis yaitu mampu menyerap air. Menurut Sanjaya et al. (2016), penambahan ekstrak rosela dengan konsentrasi berbeda menyebabkan perbedaan kadar air yang dihasilkan pada terasi. Hal ini diduga karena menurunnya kadar garam setiap penambahan konsentrasi perlakuan, dimana garam berfungsi sebagai pengeluar air pada terasi sehingga kemampuan untuk mengurangi air pada terasi juga berkurang. Garam yang bersifat higroskopis yang menyebabkan berkurangnya jumlah air.

\section{Kadar Garam Terasi}

Hasil rata-rata nilai kadar garam terasi udang rebon (Acetes sp.) dengan perbedaan penambahan konsentrasi pewarna alami ekstrak kulit buah naga (Hylocereus polyrhizus) disajikan pada Tabel 2.

Tabel 2 Hasil Uji Kadar Garam Terasi Udang Rebon (Acetes sp.) dengan Penambahan Pewarna Alami Ekstrak Kulit Buah Naga (Hylocereus polyrhizus)

\begin{tabular}{lc}
\hline \multicolumn{1}{c}{ Perlakuan } & $(\%)$ \\
\hline K $(0 \%)$ & $7,05 \pm 0,07^{\mathrm{a}}$ \\
A $(30 \%)$ & $6,85 \pm 0,06^{\mathrm{b}}$ \\
B $(35 \%)$ & $6,55 \pm 0,04^{\mathrm{c}}$ \\
C $(40 \%)$ & $6,35 \pm 0,04^{\mathrm{d}}$ \\
\hline
\end{tabular}

Keterangan:

- Data merupakan hasil rata-rata 3 kali ulangan \pm standar deviasi

- Data yang diikuti huruf superscript yang berbeda menunjukkan perbedaan nyata $(\mathrm{P}<5 \%)$

Berdasarkan uji kadar garam pada terasi yang telah dilakukan, didapatkan nilai berkisar antara 6,35-7,05\%. Nilai tertinggi yang diperoleh yaitu $7,05 \%$ pada terasi $\mathrm{K}$, kemudian $6,85 \%$ pada terasi A, 6,55\% pada terasi $\mathrm{B}$, dan nilai terendah yaitu $6,35 \%$ pada terasi C. Hasil tersebut menunjukkan kadar garam terasi sesuai dengan SNI 2716:2016 (2016) yang menyatakan bahwa kadar garam terasi maksimal $20 \%$.

Nilai kadar garam pada terasi mengalami penurunan sebesar 2-9\%. Hasil tersebut menunjukkan bahwa semakin tinggi 
konsentrasi pewarna alami ekstrak kulit buah naga (Hylocereus polyrhizus) yang ditambahkan, maka kadar garam pada terasi akan menurun. Penurunan nilai tersebut sesuai dengan penelitian Sanjaya et al. (2016), tentang nilai kadar garam dari perlakuan penambahan rosella dengan konsentrasi berbeda, masing-masing memiliki nilai rata- rata yang berbeda. Penambahan rosella 5\% memiliki nilai kadar garam $6,71 \%$, pada penambahan rosella $10 \%$ memiliki nilai kadar garam $6,26 \%$, dan pada penambahan rosella $15 \%$ memiliki nilai $5,63 \%$.

\section{Derajat Keasaman (pH) Terasi}

Hasil rata-rata nilai $\mathrm{pH}$ terasi udang rebon (Acetes sp.) dengan perbedaan penambahan konsentrasi pewarna alami ekstrak kulit buah naga (Hylocereus polyrhizus) disajikan pada Tabel 3.

Tabel 3 Hasil Uji pH Terasi Udang Rebon (Acetes sp.) dengan Penambahan Pewarna Alami Ekstrak Kulit Buah Naga (Hylocereus polyrhizus)

\begin{tabular}{lc}
\hline \multicolumn{1}{c}{ Perlakuan } & $(\%)$ \\
\hline K $(0 \%)$ & $7,20 \pm 0,08^{\mathrm{a}}$ \\
A $(30 \%)$ & $6,87 \pm 0,04^{\mathrm{ab}}$ \\
B $(35 \%)$ & $6,65 \pm 0,06^{\mathrm{b}}$ \\
C $(40 \%)$ & $6,40 \pm 0,05^{\mathrm{c}}$ \\
\hline
\end{tabular}

Keterangan:

- Data merupakan hasil rata-rata 3 kali ulangan \pm standar deviasi

- Data yang diikuti huruf superscript yang berbeda menunjukkan perbedaan nyata $(\mathrm{P}<5 \%)$

Berdasarkan uji $\mathrm{pH}$ pada terasi yang telah dilakukan, didapatkan nilai berkisar antara 6,40-7,20\%. Nilai tertinggi yang diperoleh yaitu 7,20 pada terasi $\mathrm{K}$, kemudian 6,87 pada terasi $\mathrm{A}, 6,65$ pada terasi $\mathrm{B}$, dan nilai terendah yaitu 6,40 pada terasi C. Hasil tersebut menunjukkan bahwa terasi dengan berbeda perlakuan bersifat asam. Hasil nilai pH pada penelitian Sari et al. (2009), masing-masing mempunyai nilai rata-rata $6,83,5,82$ dan 5,66. Nilai $\mathrm{pH}$ tertinggi sebesar 6,83, yaitu pada terasi ikan tanpa penambahan ekstrak rosela (A0) dan kadar $\mathrm{pH}$ terendah sebesar 5,66, yaitu pada perlakuan terasi ikan dengan penambahan ekstrak rosela $20 \%$ (A2).
Salah satu faktor yang mempengaruhi proses fermentasi pada terasi adalah $\mathrm{pH}$. Nilai $\mathrm{pH}$ pada terasi mengalami penurunan sebesar $4-11 \%$. Penurunan nilai $\mathrm{pH}$ dengan penambahan konsentrasi pewarna alami ekstrak kulit buah naga (Hylocereus polyrhizus) diduga terjadi karena sifat asam dari kulit buah naga sehingga akan mempengaruhi nilai $\mathrm{pH}$ pada terasi. Menurut Wahyuni (2011), penurunan $\mathrm{pH}$ dengan meningkatnya persentase penambahan kulit buah naga disebabkan karena pada kulit mengandung asam sehingga dengan penambahan kulit dapat mengakibatkan $\mathrm{pH}$ turun. Hal ini diperkuat oleh Jaafar et al. (2009), kandungan asam askorbat (vitamin C) pada kulit buah naga adalah 8-9 mg sehingga semakin tinggi konsentrasi pewarna kulit buah naga yang ditambahkan mengakibatkan nilai $\mathrm{pH}$ menjadi semakin rendah.

\section{Kadar Protein Terasi}

Hasil rata-rata nilai kadar protein terasi udang rebon (Acetes sp.) dengan perbedaan penambahan konsentrasi pewarna alami ekstrak kulit buah naga (Hylocereus polyrhizus) disajikan pada Tabel 4.

Tabel 4 Hasil Uji Kadar Protein Terasi Udang Rebon (Acetes sp.) dengan Penambahan Pewarna Alami Ekstrak Kulit Buah Naga (Hylocereus polyrhizus)

\begin{tabular}{lcc}
\hline Perlakuan & BB (\%) & BK (\%) \\
\hline K (0\%) & $26,43 \pm 0,22^{\mathrm{a}}$ & $35,93 \pm 0,41^{\mathrm{a}}$ \\
A $(30 \%)$ & $26,53 \pm 0,18^{\mathrm{a}}$ & $36,11 \pm 0,33^{\mathrm{a}}$ \\
B $(35 \%)$ & $27,02 \pm 0,36^{\mathrm{a}}$ & $36,07 \pm 0,03^{\mathrm{a}}$ \\
C $(40 \%)$ & $26,51 \pm 0,02^{\mathrm{a}}$ & $37,03 \pm 0,68^{\mathrm{a}}$ \\
\hline
\end{tabular}

Keterangan:

- Data merupakan hasil rata-rata 3 kali ulangan \pm standar deviasi

- Data yang diikuti huruf superscript yang berbeda menunjukkan perbedaan nyata $(\mathrm{P}<5 \%)$

Berdasarkan uji kadar protein pada terasi yang telah dilakukan, didapatkan nilai berkisar antara 35,93-37,03\% menunjukkan kadar protein terasi masih sesuai dengan SNI 2716:2016 (2016) yang menyatakan bahwa kadar protein terasi minimal $15 \%$. Menurut Adawyah (2007), kadar protein terasi sekitar 20-45\%, maka dari itu terasi dengan 
penambahan pewarna alami ekstrak kulit buah naga (Hylocereus polyrhizus) dapat diterima.

Hasil kadar protein terasi menunjukkan bahwa semakin tinggi konsentrasi pewarna alami ekstrak kulit buah naga (Hylocereus polyrhizus) yang ditambahkan, maka tidak berpengaruh nyata terhadap kadar protein pada terasi. Menurut Wahyuni dan Matheus (2014), di dalam ekstrak kulit buah naga merah hanya mengandung protein sebesar 0,53 gram per 100 gram kulit buah naga.

Salah satu faktor yang dapat mempengaruhi kadar protein adalah kadar air. Semakin tinggi kadar air, maka semakin rendah kadar proteinnya. Menurut Arjuan (2008), kadar protein dipengaruhi oleh kadar air, semakin tinggi kadar air dalam suatu bahan, maka presentasi protein dan komponen lainnya akan lebih rendah jika dibandingkan dengan suatu produk yang identik namun memiliki kadar air yang lebih rendah.

\section{Karakteristik Warna Terasi}

Hasil rata-rata pengujian warna (chromameter) terasi udang rebon (Acetes sp.) dengan penambahan pewarna alami ekstrak kulit buah naga (Hylocereus polyrhizus) tersaji pada Tabel 5.

Tabel 5 Hasil Pengujian Warna pada Terasi dengan Chromameter

\begin{tabular}{lcccc}
\hline \multirow{2}{*}{ Perlakuan } & \multicolumn{3}{c}{ Warna } & \multirow{2}{*}{${ }^{\circ}$ Hue } \\
\cline { 2 - 4 } & $\mathrm{L}$ & $\mathrm{a}^{*}$ & $\mathrm{~b}^{*}$ & \\
\hline K $(0 \%)$ & $42,80 \pm 0,20^{\mathrm{a}}$ & $2,09 \pm 0,06^{\mathrm{a}}$ & $1,73 \pm 0,06^{\mathrm{a}}$ & $39,62 \pm 0,99^{\mathrm{a}}$ \\
$\mathrm{A}(30 \%)$ & $40,27 \pm 0,17^{\mathrm{b}}$ & $2,36 \pm 0,03^{\mathrm{ab}}$ & $2,43 \pm 0,13^{\mathrm{b}}$ & $45,71 \pm 1,43^{\mathrm{b}}$ \\
$\mathrm{B}(35 \%)$ & $40,17 \pm 0,67^{\mathrm{b}}$ & $2,57 \pm 0,08^{\mathrm{bc}}$ & $3,13 \pm 0,28^{\mathrm{c}}$ & $50,50 \pm 1,80^{\mathrm{bc}}$ \\
$\mathrm{C}(40 \%)$ & $37,90 \pm 0,76^{\mathrm{c}}$ & $2,78 \pm 0,13^{\mathrm{c}}$ & $3,54 \pm 0,11^{\mathrm{c}}$ & $51,87 \pm 2,05^{\mathrm{c}}$ \\
\hline
\end{tabular}

Keterangan:

- Data merupakan hasil rata-rata 3 kali ulangan \pm standar deviasi

- Data yang diikuti huruf superscript yang berbeda menunjukkan perbedaan nyata $(\mathrm{P}<5 \%)$

\section{Nilai L (Kecerahan / lightness)}

Berdasarkan uji nilai kecerahan pada terasi yang telah dilakukan, didapatkan nilai berkisar antara 37,90-42,80. Nilai L yang diperoleh pada terasi yaitu 42,80 untuk terasi $\mathrm{K}, 40,27$ untuk terasi $\mathrm{A}, 40,17$ untuk terasi B, dan 37,90 untuk terasi C. Nilai tersebut termasuk dalam indikasi warna gelap karena berada di bawah angka 50. Menurut Sanjaya et al. (2016), kecerahan hasil penelitian menunjukkan rentangan nilai kecerahan antara 38,17-41,34. Nilai tersebut termasuk dalam indikasi warna gelap karena berada di bawah angka 50. Hal ini juga diperkuat oleh Hunterlab (2012), nilai L (kecerahan) dengan angka rendah (050) mengindikasikan kegelapan warna, sedangkan nilai L dengan angka tinggi (51100) mengindikasikan kecerahan warna.

Nilai kecerahan (L) menunjukkan bahwa penambahan pewarna kulit buah naga memberikan perbedaan kecerahan. Terasi dengan penambahan pewarna kulit buah naga memiliki nilai kecerahan yang lebih rendah dibandingkan dengan terasi tanpa penambahan pewarna kulit buah naga. Semakin meningkatnya konsentrasi yang digunakan, maka semakin rendah nilai kecerahannya. Peningkatan konsentrasi pewarna kulit buah naga tersebut menyebabkan meningkatnya warna merah sehingga cahaya pada terasi yang ditambahkan pewarna semakin rendah.

Menurut penelitian Arjuan (2008), semakin meningkatnya konsentrasi yang digunakan, maka nilai kecerahan terasi semakin rendah. Hal ini disebabkan karena peningkatan konsentrasi pewarna bit meningkatkan intensitas warna merah terasi, sehingga cahaya yang dipantulkan oleh permukaan terasi yang diberi pewarna semakin rendah atau absorbansi terhadap cahaya pada permukaan terasi semakin tinggi. Dalam aplikasinya pada terasi, warna alami terasi sendiri tanpa menggunakan pewarna secara visual cenderung berwarna coklat tua. Dengan memudarnya warna merah pada terasi, maka warna asli dari terasi muncul lebih dominan. Warna coklat menyerap lebih banyak cahaya dibandingkan warna merah sehingga menyebabkan nilai $\mathrm{L}$ 
menjadi lebih kecil. Oleh karena itu sangat jelas seiring dengan berjalannya waktu fermentasi, maka nilai kecerahan produk terasi semakin menurun.

Faktor lain yang dapat mempengaruhi nilai kecerahan pada terasi adalah proses penjemuran. Proses penjemuran dapat mengakibatkan diskolorasi produk sehingga warna menjadi semakin lebih gelap. Menurut Rahmayati et al. (2014), kenampakan terasi terlihat lebih gelap diakibatkan juga oleh proses oksidasi saat penjemuran. Ketika penjemuran dilakukan proses oksidasi pigmen astaxanthin tidak dapat dihindari sehingga mengakibatkan proses pencoklatan. Proses oksidasi astaxanthin bebas dapat mengakibatkan diskolorisasi produk sehingga warna menjadi gelap.

\section{Nilai a* ( Merah / Hijau )}

Berdasarkan uji nilai a pada terasi yang telah dilakukan, didapatkan nilai berkisar antara 2,09-2,78. Nilai tertinggi yang diperoleh yaitu 2,78 pada terasi $\mathrm{C}, 2,57$ pada terasi B, 2,36 pada terasi A, dan nilai terendah yaitu 2,09 pada terasi K. Hasil tersebut membuktikan bahwa semakin meningkatnya konsentrasi pewarna yang digunakan, maka warna merah (nilai a) pada terasi juga semakin meningkat. Menurut Arjuan (2008), nilai a tertinggi pada konsentrasi $7 \%$ sedangkan terendah terdapat pada konsentrasi pewarna $3 \%$ semakin meningkat konsentrasi pewarna bit yang digunakan maka nilai a semakin tinggi.

Peningkatan nilai a pada terasi disebabkan oleh pewarna yang terkandung dalam terasi. Pewarna yang terbuat dari kulit buah naga mengandung antosianin. Antosianin merupakan zat warna alami berwarna merah. Menurut Saati (2009), penambahan intensitas warna merah $(\mathrm{a}+)$ dengan meningkatnya penambahan ekstrak kulit buah naga merah disebabkan karena ekstrak kulit buah naga merah mengandung antosianin yaitu zat warna alami yang terdapat dalam kulit buah naga merah yang berwarna merah. Hal ini juga diperkuat oleh Khotijah (2016), kulit buah naga sendiri mengandung zat warna alami antosianin yang cukup tinggi. Antosianin merupakan zat warna yang berperan untuk memberikan warna merah yang berpotensi sebagai pemberi warna alami dan dapat pula dijadikan alternatif pengganti pewarna sintetis yang lebih aman bagi kesehatan.

Terasi tanpa penambahan pewarna memiliki warna merah kecoklatan. Warna yang dihasilkan tersebut diduga karena terdapat pigmen astaxanthin. Astaxanthin merupakan sumber warna merah pada udang. Menurut Suprapti (2006), warna kemerahan pada terasi udang berasal dari pigmen astaxanthin pada cangkang udang sehingga pigmen tersebut membentuk warna merah. Hal ini juga diperkuat oleh Rahmayati et al. (2014), warna kecoklatan terbentuk pada terasi berbahan baku udang karena mengandung astaxanthin. Astaxanthin merupakan pigmen turunan dari karotenoid yang membawa warna merah.

Menurut Li et al. (2006), antosianin merupakan senyawa yang berwarna merah sehingga jika terjadi reaksi pencoklatan dapat diketahui bahwa telah terjadi degradasi antosianin. Antosianin dapat dengan mudah mengalami degradasi. Proses degradasi ini diakibatkan oleh proses enzimatik. Pada umumnya, degradasi antosianin dapat terjadi karena adanya enzim polifenol oksidase. Secara enzimatis, kehadiran enzim polifenol oksidase mempengaruhi kestabilan antosianin karena bersifat merusak antosianin. Enzim yang berperan adalah enzim polifenol oksidase dan peroksidase yang mengkatalis proses oksidasi yang nantinya membentuk quinon serta enzim glukosidase yang mempercepat pemecahan ikatan glikosidik. Aktivitas enzim polifenol oksidase membuat warna ekstrak antosianin menjadi kecoklatan. Aktivitas enzim ini dapat menyebabkan proses brown pigment yaitu perubahan warna antosianin menjadi coklat yang menandakan telah terjadi degradasi pada antosianin. Polifenol oksidase (PPO) mengkatalisis terjadinya hidroksilasi dan oksidasi senyawa fenol dalam molekul oksigen.

\section{Nilai b* ( Kuning / Biru )}

Berdasarkan uji nilai b pada terasi yang telah dilakukan, didapatkan nilai berkisar antara 1,73-3,54. Nilai tertinggi yang diperoleh yaitu 3,54 pada terasi C, 3,13 pada 
terasi $\mathrm{B}, 2,43$ pada terasi $\mathrm{A}$, dan nilai terendah yaitu 1,73 pada terasi $K$. Hasil tersebut membuktikan bahwa semakin meningkatnya konsentrasi pewarna yang digunakan, maka warna kuning (nilai b) pada terasi juga semakin meningkat. Menurut penelitian Sanjaya et al. (2016), warna kuning atau yellowness $(+b)$ pada terasi menunjukkan nilai antara 1,66-4,23. Semakin banyak penambahan ekstrak rosella akan mempengaruhi warna kuning pada terasi.

Hasil nilai b pada terasi menunjukkan bahwa terasi memiliki warna yang cenderung kekuningan. Apabila nilai b semakin positif, maka warna yang akan dihasilkan adalah semakin kuning. Menurut Safitri (2009), nilai $b$ menunjukkan derajat kuning biru sampel. Semakin positif (naik) suatu nilai b maka sampel semakin berwarna kuning dan sebaliknya bila semakin negatif (menurun) maka sampel semakin berwarna biru. Hal ini juga diperkuat oleh Gilmunoz et al. (1998) dalam Rahmayati et al. (2014), nilai b* menunjukkan warna kekuningan sedangkan $-b^{*}$ menunjukkan warna kebiruan. Notasi $b^{*}$ menyatakan warna kromatik campuran kuning biru dengan nilai positif $\left(+b^{*}\right) 0-70$ dan negatif $(-b *) 0-(-70)$.

\section{Nilai ${ }^{\circ} \mathrm{Hue}$}

Hasil dari pengujian dengan chromameter menghasilkan nilai $a^{*}$ dan $b^{*}$. Perhitungan nilai $a^{*}$ dan $b^{*}$ dapat menentukan nilai derajat Hue ( ${ }^{\circ} \mathrm{Hue}$ ). Menurut Arjuan (2008), menjelaskan nilai L, $a^{*}, b^{*}$ menunjukkan koordinat dalam ruang tiga dimensi yang berhubungan dengan kecerahan (L) dan derajat hue ( ${ }^{\circ} \mathrm{Hue}$ ). Derajat hue merupakan bagian dalam sensasi visual yang mengacu pada penerimaan warna merah, kuning, hijau, atau biru.

Berdasarkan uji nilai hue pada terasi yang telah dilakukan, didapatkan nilai berkisar antara 39,62-51,87. Nilai tertinggi yang diperoleh yaitu 51,87 pada terasi C, 50,50 pada terasi $\mathrm{B}, 45,71$ pada terasi $\mathrm{A}$, dan nilai terendah yaitu 39,02 pada terasi $\mathrm{K}$. Hasil tersebut menunjukkan bahwa terasi memiliki warna yang mengarah ke merah (red). Hasil uji statistika menunjukkan bahwa setiap perlakuan pada terasi berpengaruh nyata terhadap nilai derajat hue.
Menurut Arjuan (2008), terasi udang umumnya memiliki warna yang mengarah ke merah (red) atau yellow red. Terasi memiliki warna red jika ${ }^{\circ}$ hue $18^{\circ}-54^{\circ}$ dan berwarna yellow red jika ohue $54^{\circ}-90^{\circ}$.

Antosianin dapat mengalami degradasi akibat perubahan suhu dan $\mathrm{pH}$. Hal ini yang diduga dapat mengakibatkan perbedaan nilai terhadap warna pada terasi setelah ditambahkan pewarna kulit buah naga. Menurut Samber et al. (2015), pigmen antosinanin merupakan molekul yang tidak stabil jika terjadi perubahan pada suhu. Suhu yang panas $\left(>50^{\circ} \mathrm{C}\right.$ ) dapat menyebabkan kerusakan struktur antosianin. Kerusakan warna antosianin disebabkan oleh berubahnya kation flavilium yang berwarna merah menjadi basa karbinol yang tidak berwarna dan akhirnya menjadi khalkone yang tidak berwarna. Cahaya juga berperan dalam laju degradasi warna antosianin. Cahaya, seperti halnya panas, mampu mendegradasi pigmen antosianin dan membentuk kalkon yang tidak berwarna. Energi yang dikeluarkan oleh cahaya memicu terjadinya reaksi fitokimia yang dapat membuka cincin antosianin. Paparan yang lebih lama menyebabkan terjadinya degradasi. Antosianin lebih stabil dalam larutan asam dibandingkan dalam larutan basa. Pada $\mathrm{pH}$ 1-5 antosianin berbentuk kation flavinium yang memberikan warna merah dan pada $\mathrm{pH}$ yang lebih tinggi yaitu $>6$ terdapat dua senyawa yang tidak berwarna yaitu karbinol pseudobasa dan kalkon.

\section{Pengujian Sensori}

\section{Terasi}

Pengujian sensori pada terasi dilakukan berdasarkan penilaian panelis terhadap sampel yang meliputi kenampakan, aroma, rasa, dan tekstur pada produk pangan. Pengujian tersebut menggunakan lembar penilaian sensori terasi udang SNI 2761.1:2016. Skala penilaian pada lembar penilaian sensori terasi udang adalah 1-9 yang akan dinilai oleh 30 panelis. Hasil ratarata uji sensori terasi udang rebon (Acetes sp.) dengan penambahan pewarna alami ekstrak kulit buah naga (Hylocereus polyrhizus) tersaji pada Tabel 6. 
Berdasarkan hasil uji Kruskall Wallis pada nilai rata-rata sensori terasi menunjukkan bahwa perbedaan penambahan konsentrasi pewarna alami ekstrak kulit buah naga (Hylocereus polyrhizus) tidak berpengaruh nyata $(\mathrm{P}>5 \%)$ sehingga perlakuan tidak memberikan pengaruh terhadap rata-rata nilai sensori terasi. Hasil uji rata-rata nilai sensori terasi menunjukkan nilai rata-rata sebesar 7,36-7,53. Berdasarkan hasil tersebut, maka terasi layak dikonsumsi karena nilai sensori lebih dari 7 . Menurut Aristyan et al. (2014), nilai rerata tingkat penerimaan terhadap kenampakan terasi rebon dapat diterima oleh konsumen karena lebih tinggi dari persyaratan nilai minimum produk terasi menurut SNI yaitu 7,0 .

\section{Kenampakan}

Kenampakan merupakan karakteristik penilaian panelis terhadap suatu produk dengan mengkombinasikan warna hingga tekstur suatu produk. Warna merupakan salah satu unsur kualitas sensori yang paling penting dalam penilaian panelis terhadap kenampakan terasi karena hal yang pertama kali akan dilihat oleh panelis adalah warna pada suatu produk. Berdasarkan uji Kruskal Wallis terhadap kenampakan terasi dengan perbedaan penambahan konsentrasi pewarna alami ekstrak kulit buah naga (Hylocereus polyrhizus) menunjukkan bahwa terdapat pengaruh nyata $(\mathrm{P}<5 \%)$ antar perlakuan. Selanjutnya dilakukan uji lanjut Mann Whitney yang menunjukkan bahwa terdapat perbedaan nyata $(\mathrm{P}<5 \%)$ antar

Tabel 6 Nilai Sensori Terasi Udang Rebon (Acetes sp.) dengan Penambahan Pewarna Alami Ekstrak Kulit Buah Naga (Hylocereus polyrhizus)

\begin{tabular}{lcccc}
\hline \multirow{2}{*}{ Spesifikasi } & \multicolumn{4}{c}{ Perlakuan } \\
\cline { 2 - 5 } & $\mathrm{K}(0 \%)$ & $\mathrm{A}(30 \%)$ & $\mathrm{B}(35 \%)$ & $\mathrm{C}(40 \%)$ \\
\hline Kenampakan & $7,33 \pm 1,27^{\mathrm{a}}$ & $7,66 \pm 1,29^{\mathrm{ab}}$ & $8,00 \pm 1,00^{\mathrm{b}}$ & $8,20 \pm 0,97^{\mathrm{b}}$ \\
Bau & $7,73 \pm 1,09^{\mathrm{a}}$ & $7,53 \pm 0,88^{\mathrm{a}}$ & $7,40 \pm 0,95^{\mathrm{a}}$ & $7,46 \pm 0,84^{\mathrm{a}}$ \\
Rasa & $7,43 \pm 0,84^{\mathrm{a}}$ & $7,00 \pm 1,03^{\mathrm{a}}$ & $7,46 \pm 1,11^{\mathrm{a}}$ & $7,33 \pm 0,74^{\mathrm{a}}$ \\
Tekstur & $7,06 \pm 0,81^{\mathrm{a}}$ & $7,26 \pm 0,85^{\mathrm{a}}$ & $7,13 \pm 1,25^{\mathrm{a}}$ & $7,13 \pm 1,02^{\mathrm{a}}$ \\
\hline Rata - Rata & $7,40 \pm 0,45^{\mathrm{a}}$ & $7,36 \pm 0,51^{\mathrm{a}}$ & $7,50 \pm 0,46^{\mathrm{a}}$ & $7,53 \pm 0,38^{\mathrm{a}}$ \\
\hline
\end{tabular}

Keterangan:

- Data merupakan hasil rata-rata 3 kali ulangan \pm standar deviasi

- Data yang diikuti huruf superscript yang berbeda menunjukkan perbedaan nyata $(\mathrm{P}<5 \%)$

\section{Bau}

Bau merupakan faktor yang mempengaruhi ketertarikan konsumen terhadap suatu bahan pangan. Nilai perlakuan dengan hasil nilai kenampakan terasi $\mathrm{K}$ berbeda nyata dengan terasi $\mathrm{B}$ dan C.

Berdasarkan pengujian statistik menunjukkan bahwa penambahan pewarna memberikan pengaruh nyata terhadap nilai sensori kenampakan terasi. Kenampakan terasi dengan penambahan pewarna berbeda dengan terasi tanpa penambahan pewarna. Terasi $\mathrm{C}$ dengan nilai tertinggi yaitu 8,20 berwarna lebih merah dibandingkan dengan terasi yang lain. Menurut Rahman dan Iffan (2016), kesukaan panelis terhadap warna semakin tinggi seiring dengan semakin tinggi penambahan bubuk kulit manggis pada terasi udang. Hal ini disebabkan oleh penambahan bubuk kulit manggis menyebabkan semakin tinggi konsetrasi kandungan antosianin yang terkandung dalam terasi udang sehingga mengakibatkan warna terasi lebih berwarna merah daripada tanpa ditambahkan bubuk kulit manggis yang warnanya lebih pucat dan pudar.

Panelis menilai kenampakan dengan melihat warna dari terasi karena warna merupakan hal pertama kali diperhatikan oleh panelis. Menurut Sari et al. (2009), kesan pertama yang didapat konsumen adalah melalui kenampakan dari produk, umumnya konsumen lebih tertarik pada produk dengan kenampakan yang baik. Warna penting bagi banyak produk baik yang sudah diproses ataupun belum diproses, dikarenakan warna memegang peranan bagi penerimaan konsumen dan merupakan indikasi perubahan kimia. sensori terhadap bau terasi berkisar antara 7,40-7,73. Berdasarkan hasil tersebut, maka terasi memiliki bau yang sama yaitu kurang spesifik terasi udang. Bau terasi dapat 
dipengaruhi oleh proses fermentasi. Menurut Aristyan et al. (2014), bau dan rasa khas terasi merupakan salah satu daya tarik konsumen. Bau yang terbentuk pada terasi dipengaruhi oleh adanya senyawa volatil pada terasi akibat proses fermentasi. Hal ini juga diperkuat oleh Rahman dan Iffan (2016), aroma terasi dihasilkan oleh fermentasi terasi. Aroma yang muncul pada terasi berasal dari asam lemak yang bersifat volatil (bau keasaman), amonia dan amin (anyir beramonia). Salah satu komponen pembentuk cita rasa dan aroma terasi yaitu senyawa belerang sederhana seperti sulfida, dan disulfida yang menyebabkan bau pada terasi tersebut.

\section{Rasa}

Rasa merupakan parameter kesukaan yang menentukan tingkat penerimaan atau penolakan konsumen terhadap suatu produk. Nilai sensori terhadap rasa terasi berkisar antara 7,00-7,46. Berdasarkan hasil tersebut, maka terasi memiliki rasa yang sama yaitu spesifik terasi udang. Rasa yang dihasilkan terasi berasal dari protein yang berubah menjadi asam-asam amino. Menurut Sari et al. (2009), rasa terasi yang khas berasal dari protein menjadi asam-asam amino yang dapat menimbulkan cita rasa yang enak. Hal ini juga diperkuat oleh Karim (2014), selama proses fermentasi terjadi proses pemecahan protein menjadi asam-asam amino yang salah satunya adalah asam glutamat yang merupakan sumber rasa umami dari terasi.

\section{Tekstur}

Tekstur merupakan faktor yang menentukan tingkat penerimaan konsumen menggunakan indra peraba. Nilai sensori terhadap tekstur terasi berkisar antara 7,067,26 . Berdasarkan hasil tersebut, maka terasi memiliki tekstur yang sama yaitu tekstur yang padat kurang kompak. Tekstur terasi dapat dipengaruhi oleh kadar air sehingga penambahan air saat proses pembuatan terasi akan berpengaruh terhadap tekstur terasi. Menurut Arjuan (2008), dengan penambahan pewarna bit, maka setelah proses penjemuran terasi ditambahkan lagi sedikit air untuk menghomogenkan pewarna bit bubuk dengan terasi. Adanya penambahan air akan meningkatkan kadar air yang berpengaruh terhadap tekstur terasi yang dihasilkan.

\section{KESIMPULAN}

Berdasarkan data hasil penelitian dan pembahasan, didapatkan kesimpulan sebagai berikut:

1. Penambahan ekstrak kulit buah naga sebagai pewarna alami akan menurunkan kadar garam dan $\mathrm{pH}$, meningkatkan kadar air, meningkatkan warna merah, serta memperbaiki kenampaka terasi.

2. Konsentrasi penambahan ekstrak kulit buah naga terbaik pada terasi adalah $40 \%$ karena memberikan hasil yang nyata terhadap perubahan warna.

\section{DAFTAR PUSTAKA}

2006. Standar Nasional Indonesia No. 2354.2-2006. Badan Standarisasi Nasional (BSN). Jakarta. 2016. Standar Nasional Indonesia 2716:2016. Badan Standarisasi Nasional (BSN). Jakarta.

Adawyah, R. 2007. Pengolahan dan Pengawetan Ikan. Bumi Aksara, Jakarta, 159 hlm. Andriyani, E.A., Yuliati K., dan Supriadi A. 2012. Efisiensi dan Identifikasi Loss pada Proses Pengolahan Terasi Udang Rebon (Acetes sp.) di Desa Belo Laut Kecamatan Muntok Bangka Belitung. Fishtech., 1(1).

AOAC. 2005. Official Methods of Analysis of the Association of Official Analytical Chemist. Inc., Washington, DC.

Aristyan, I., Ratna I., dan Laras R. 2014. Pengaruh Perbedaan Kadar Garam terhadap Mutu Organoleptik dan Mikrobiologis Terasi Rebon (Acetes sp.). Jurnal Pengolahan dan Bioteknologi Hasil Perikanan, 3(2): 60-66.

Arjuan, H. 2008. Aplikasi Pewarna Bubuk Ekstrak Umbi Bit (Beta vulgaris) Sebagai Pengganti Pewarna Tekstil pada Produk Terasi Kabupaten Berau Kalimantan Timur. [Skripsi]. Program Studi Teknologi Hasil Perikanan, Fakultas Perikanan dan Ilmu Kelautan, Institut Pertanian Bogor, Bogor, 107 hlm. 
Asmaraningtyas, D. 2014. Kekerasan, Warna dan Daya Terima Biskuit yang Disubstitusi Tepung Labu Kuning. [Naskah Publikasi]. Program Studi Ilmu Gizi Jenjang S1, Fakultas Ilmu Kesehatan, Universitas Muhammadiyah Surakarta, $17 \mathrm{hlm}$.

Badan Standarisasi Nasional. 1992. Cara Uji Makanan dan Minuman SNI No. 012891-1992. Badan Standarisasi Nasional Indonesia (BSNI). Jakarta.

Citramukti, I. 2008. Ekstraksi dan Uji Kualitas Pigmen Antosianin pada Kulit Buah Naga Merah (Hylocereus costaricensis). [Skripsi]. Jurusan Teknologi Hasil Pertanian, Fakultas Pertanian, Universitas Muhammadiyah Malang. Malang.

Dharmawan, I.P.G.A. 2009. Pengaruh Kopigmentasi Pewarna Alami Antosianin dari Rosela (Hibiscus sabdariffa L.) dengan Brazilein dari Kayu Secang (Caesalpinia sappan L.) terhadap Stabilitas Warna pada Model Minuman Ringan. [Skripsi]. Fakultas Teknologi Pertanian, Institut Pertanian Bogor, Bogor, 148 hlm.

Elastri, A. 2015. Pengaruh Substitusi Ekstrak Kulit Buah Naga Merah terhadap Kualitas Es Krim. [Skripsi]. Program Studi Pendidikan Kesejahteraan Keluarga, Jurusan Kesejahteraan Keluarga, Fakultas Teknik, Universitas Negeri Padang, $17 \mathrm{hlm}$.

Fitriyani, R., R. Utami, dan E. Nurhartadi. 2013. Kajian Karakteristik Fisikokimia dan Sensori Bubuk Terasi Udang dengan Penambahan Angkak Sebagai Pewarna Alami dan Sumber Antioksidan. Jurnal Teknosains Pangan., 2(1): 97-106.

Hanafiah, K.A. 2005. Rancangan Percobaan Teori dan Aplikasi. Raja Grafindo Persada, Jakarta.

Hariyanto, N., Dwi R., dan Hery K. 2013. Upaya Peningkatkan Kualitas dan Produksi Pencacahan Udang Rebon Menjadi Terasi dengan Aplikasi Mesin Extruder. [Tugas Akhir]. Program Studi Diploma III Teknik Mesin, Fakultas Teknik,
Universitas Diponegoro, Semarang, $24 \mathrm{hlm}$.

Harjanti, R.S. 2016. Optimasi Pengambilan Antosianin dari Kulit Buah Naga Merah (Hylocereus polyrhizus) Sebagai Pewarna Alami pada Makanan. Chemica., 3(2): 39-45.

Hunterlab. 2012. Hunter $L$, $a, b$, vs CIE $L^{*}$, $a^{*}, b^{*}$ : Measuring Color Using Hunter $L, a, b$, versus CIE $1976 L^{*}$, $a^{*}, b^{*}$. Hunter Associates Laboratory Inc. http://www.hunterlab.com (Diakses pada tanggal 3 September 2015).

Indriati, N., dan Fairdiana A. 2012. Pemanfaatan Angkak Sebagai Pewarna Alami pada Terasi Udang. JPB Perikanan., 7(1): 11-20.

Ingrath, W., Wahyunanto A.N., dan Rini Y. 2015. Ekstraksi Pigmen Antosianin dari Kulit Buah Naga Merah (Hylocereus costaricensis) sebagai Pewarna Alami Makanan dengan Menggunakan Microwave. Jurnal Bioproses Komoditas Tropis, 3(3): 18.

Instruction Manual. 2002. HygroPalm AW1Portable Water Activity Indicator. East Main Street, Hurington, New York.

Jaafar, Ali, R., Nazri, M., dan Khairuddin, W. 2009. Proximate Analysis of Dragon Fruit (Hylecereus polyhizus). American Journal of Applied Sciences. $6: 1341-1346$.

Karim, F.A., Fronthea S., dan Apri D.A. 2014. Pengaruh Perbedaan Bahan Baku terhadap Kandungan Asam Glutamat pada Terasi. Jurnal Pengolahan dan Bioteknologi Hasil Perikanan., 3(4): 51-58.

Khotijah, S. 2016. Kadar Karbohidrat dan Organoleptik Mie Basah Tepung Biji Nangka dengan Penambahan Kulit Buah Naga Sebagai Pewarna Alami. [Publikasi Ilmiah]. Program Studi Pendidikan Biologi, Fakultas Keguruan dan Ilmu Pendidikan, Universitas Muhammadiyah Surakarta, $14 \mathrm{hlm}$.

Li, C.W., Hsu H.W., Chen Y.C., Chiu C.C., Lin Y.L., dan Ho J.A.A. 2006. 
Antioxidant and Antiproliferative Activities of Red Pitaya. Journal Food Chemistry., 95: 319-327.

Ma'ruf, M., Komasanah S., Elly P., dan Erwan S. 2013. Penerapan Produksi Bersih pada Industri Pengolahan Terasi Skala Rumah Tangga di Dusun Selangan Laut Pesisir Bontang. Jurnal Ilmu Perikanan Tropis., 18(2): 84-93.

Majid, A., Tri W.A., dan Laras R. 2014. Pengaruh Perbedaan Konsentrasi Garam terhadap Mutu Sensori dan Kandungan Senyawa Volatil pada Terasi Ikan Teri (Stolephorus sp.). Jurnal Pengolahan dan Bioteknologi Hasil Perikanan., 3(2): 17-24.

Manihuruk, F.M. 2016. Efektivitas Ekstrak Kulit Buah Naga Merah (Hylocereus polyrhizus) Sebagai Pewarna, Antioksidan, dan Antimikroba pada Sosis Daging Sapi. Sekolah Pascasarjana, Institut Pertanian Bogor, Bogor, $42 \mathrm{hlm}$.

Martony, O., Yenni Z., dan Urbanus S. 2015. Analisis Pewarnaan dari Kulit Buah Naga Merah (Hylocereus polyrhizus) Sebagai Alternatif Pewarna Merah Makanan. Prosiding Seminar Nasional Fakultas Pertanian Universitas HKBP Nommensen Medan. 21-32.

Nazir, M. 2005. Metode Penelitian. Ghalia Indonesia, Jakarta.

Nugraheni, M. 2014. Pewarna Alami Makanan dan Potensi Fungsionalnya.

Putri, N. K. M., I W. G. G., dan I W. S. 2015. Aktivitas Antioksidan Antosianin dalam Ekstrak Etanol Kulit Buah Naga Super Merah (Hylocereus costaricensis) dan Analisis Kadar Totalnya. Jurnal Kimia., 9(2): 243251.

Rahman A., dan Iffan M. 2016. Analisis Sensoris Terasi Udang yang Ditambahi Bubuk Kulit Manggis (Garnicia mangostana L.). AGROINTEK., 10(2): 85-91.

Rahmayati, R., Putut H.R., dan Laras R. 2014. Perbedaan Konsentrasi Garam terhadap Pembentukan Warna Terasi Udang Rebon (Acetes sp.) Basah.
Jurnal Pengolahan dan Bioteknologi Hasil Perikanan., 3(1): 108-117.

Saati, E.A. 2009. Identifikasi dan Uji Kualitas Pigmen Kulit Buah Naga Merah (Hylocareus costaricensis) pada Beberapa Umur Simpan dengan Perbedaan Jenis Pelarut. Direktorat Penelitian dan Pengabdian Masyarakat, JIPTUMMDPPM, UMM. Malang.

Safitri, G.I. 2009. Pengaruh Kopigmentasi Pewarna Alami Brazilein Kayu Secang (Caesalpinia sappan L.) dengan Sinapic Acid terhadap Stabilitas Warna pada Model Minuman. [Skripsi]. Departemen Ilmu Dan Teknologi Pangan, Fakultas Teknologi Pertanian, Institut Pertanian Bogor, Bogor, $112 \mathrm{hlm}$.

Samber L.N., Haryono S., dan Budhi P. 2015. Karakteristik Antosianin Sebagai Pewarna Alami. Seminar Nasional X Pendidikan Biologi FKIP UNS. 1-4.

Sanjaya, Y.D., Sumardianto, dan Putut H.R. 2016. Pengaruh Penambahan Ekstrak Rosella (Hibiscus sabdariffa Linn.) terhadap Warna dan Kualitas pada Terasi Udang Rebon (Acetes sp.). Jurnal Pengolahan dan Bioteknologi Hasil Perikanan., 5(2): 1-9.

Sari, N.I., Edison, dan Sukirno M. 2009. Kajian Tingkat Penerimaan Konsumen terhadap Produk Terasi Ikan dengan Penambahan Ekstrak Rosela. Berkala Perikanan Terubuk., 37(2): 91-103.

Simanjuntak, L., Chairinia S., dan Fatimah. 2014. Ekstraksi Pigmen Antosianin dari Kulit Buah Naga Merah (Hylocereus polyrhizus). Jurnal Teknik Kimia USU, 3(2): 25-29.

Suprapti, M.L. 2006. Teknologi Tepat Guna: Membuat Terasi. Kanisius, Yogyakarta.

Wahyuni R., dan Matheus N. 2014. Pengaruh Penambahan Ekstrak Kulit Buah Naga Super Merah terhadap Produk Mie Kering. Jurnal Teknologi Pertanian., 15(2): 93-102.

Wahyuni, R. 2011. Pemanfaatan Kulit Buah Naga Super Merah (Hylicereus 
costaricensis) Sebagai Sumber Antioksidan dan Pewarna Alami pada Pembuatan Jelly. Jurnal Teknologi Pangan., 2(1): 68-85.

Wahyuningtias, D. 2015. The Application of Dragon Fruit Peels as a Dye in Red Velvet Cake. Binus Business Review., 6(3): 372-382.

Waladi, Vonny S.J., Faizah H. 2015. Pemanfaatan Kulit Buah Naga Merah (Hylocereus polyrhizus) Sebagai Bahan Tambahan dalam Pembuatan Es Krim. Jom Faperta., 2(1): 1-11.

Wirakusumah, E.S. 2007. Mencegah Osteoporosis Lengkap dengan 39 Jus dan 38 Resep Makanan. Penebar Swadaya, Jakarta, 50 hlm. 